\title{
SREDIŠNJI ODJEL GRADSKE KNJIŽNICE RIJEKA: IZAZOVI RADA NA DVIJE ADRESE (PERSPEKTIVA KORISNIKA I KNJIŽNIČARA)
}

\author{
CENTRAL LIBRARY \\ DEPARTMENT OF THE CITY LIBRARY RIJEKA: \\ CHALLENGS OF WORKING AT TWO DIFFERENT ADDRESSES \\ (USERS'AND LIBRARIANS' PERSPECTIVES)
}

\author{
Ljiljana Črnjar \\ Gradska knjižnica Rijeka \\ ljiljana.crnjar@gkri.hr \\ Vesna Kurilić \\ Gradska knjižnica Rijeka \\ vesna.kurilic@gkri.hr \\ Milka Šupraha-Perišić \\ Gradska knjižnica Rijeka \\ milka.supraha-perisic@gkri.hr
}

\author{
UDK / UDC 022:027(497.5 RIJEKA) \\ Istraživanje / Research \\ Prihvaćeno / Accepted: 5. 5. 2017.
}

\section{Sažetak}

Gradska knjižnica Rijeka više je od desetljeća u iščekivanju realizacije projekta nove zgrade središnje knjižnice. Nakon narušavanja statike spremišta u travnju 2015., izlaz iz krizne situacije pronađen je u raseljavanju Središnjeg odjela za odrasle na dvije lokacije. Na novu je lokaciju smještena lijepa književnost, dok je u postojećem prostoru raspoređena publicistika i stručna literatura.

Vjesnik bibliotekara Hrvatske 60, 1(2017), 261-274

ISSN 0507-1925

(C) VBH 2017. 
S obzirom na to da je riječ o jedinstvenom primjeru u knjižničnoj praksi, nakon godinu dana rada u novim uvjetima provedeno je ispitivanje zadovoljstva korisnika organizacijom knjižničnih prostora i pruženim uslugama, kao i percepcije zaposlenika o radu u promijenjenim uvjetima. Zaključci se temelje i na statističkim podacima o korištenju fonda raseljenog Središnjeg odjela u prvoj godini rada u usporedbi s prethodnim godinama.

Ključne riječi: Gradska knjižnica Rijeka, zadovoljstvo korisnika, prostor knjižnice

\section{Summary}

The City Library of Rijeka has been waiting for more than a decade for the realization of the project of a new central library building, but it has not been built yet.

When the statics walls of the library depository had collapsed in April 2015, a way out of the crisis situation was found through the relocation of the Central Department for Adults into two new locations. Fine literature was moved to a new location, while non-fiction and scientific and professional literature remained at the existing location.

Considering the fact that this is a unique crisis solution in the library practice, we have examined, after one year of working in the new conditions, the satisfaction of our users with the new organization of the library at different locations, and the offered services. Furthermore, the research has examined the attitudes of the employees towards working in the new conditions.

The research analysis has also included the statistical data on the use of the library holdings of the Central Department during the first year of its relocation as compared to the previous years.

Keywords: City Library of Rijeka, satisfaction of library users, library buildings

\section{Uvod}

Gradska knjižnica Rijeka jedna je od rijetkih knjižnica čije su središnje funkcije godinama organizirane na čak četiri lokacije: Središnji odjel za odrasle, Dječji odjel "Stribor", Odjel periodike, Narodna čitaonica.

Središnji odjel GKR na današnjoj lokaciji u Palači Modello djeluje od 1966. godine kada je tamo smješten kao u privremeno prostorno rješenje. Iako se činilo da je rješenje postalo izvjesno 2006. godine kada je potpisan ugovor o izradi projektne dokumentacije za novu zgradu središnje knjižnice na Klobučarićevu trgu, 2012. godine Grad Rijeka objavljuje da odustaje od tog projekta i najav- 
ljuje da će se prostor za Knjižnicu urediti u bivšem industrijskom kompleksu "Rikard Benčić".

Prostorni problemi Središnjeg odjela kulminiraju u travnju 2015. kada dolazi do narušavanja statike spremišta u Palači Modello. Situacija je zahtijevala hitno rješenje te je ono pronađeno $u$ raseljavanju fonda i usluga na dvije lokacije. Na novu lokaciju u zgradi Filodrammatice na Korzu, u kojem je do tada bila smještena knjižara, preseljen je fond lijepe književnosti, dok je u postojećem prostoru ostao fond publicistike i stručne literature.

\section{Cilj i svrha istraživanja, metode i polazne pretpostavke}

Narodne knjižnice, sukladno svome poslanju, zadovoljavaju informacijske, obrazovne i kulturne potrebe svih korisničkih skupina, a njihov fond, zbirke i funkcionalna organizacija trebaju tome odgovarati.

Knjižnični fond i zbirke narodnih knjižnica organizirani su u signaturne skupine koje najčešće proizlaze iz Univerzalne decimalne klasifikacije, premda su moguće i drukčije sheme. No kakva god se shema primijenila, organizacija fonda i zbirki mora biti primjerena potrebama i očekivanjima korisnika te odgovarati Standardima za narodne knjižnice koji jasno definiraju funkcionalne cjeline.

S obzirom na to da je ovdje riječ o jedinstvenom primjeru u knjižničnoj praksi, nakon godinu dana rada u novim uvjetima ispitali smo zadovoljstvo korisnika organizacijom knjižničnih prostora i pruženim uslugama, kao i percepciju zaposlenika o radu u promijenjenim uvjetima.

Mišljenje korisnika i zaposlenika utoliko je važnije jer postoje vrlo podijeljeni stavovi u političkoj i općoj javnosti o (ne)rješavanju prostornih problema Gradske knjižnice Rijeka kroz dulje razdoblje. Naime usprkos izraženom zadovoljstvu od strane osnivača ${ }^{1}$ koji je osigurao dodatni prostor za Središnji odjel Gradske knjižnice Rijeka, problem fizičkog prostora Središnjeg odjela Gradske knjižnice Rijeka i dalje ostaje otvoren.

"Kako bi uspješno ostvarila svoje ciljeve, narodna knjižnica mora biti potpuno pristupačna svim svojim korisnicima."2 Smatramo da narodna knjižnica nije "potpuno pristupačna" ako korisnici moraju prilikom svakog posjeta knjižnici razmišljati koja se signaturna skupina nalazi na pojedinoj lokaciji.

Stoga su polazne pretpostavke da raseljavanje dijela Središnjeg odjela ne predstavlja rješenje prostornog problema Knjižnice, da korisnici nisu zadovoljni time što moraju odlaziti na dvije lokacije i što moraju unaprijed znati koju građu mogu

1 Šestan Kučić, Ingrid. Tijekom 20 dana posuđeno osam tisuća naslova. // Novi list 69, 22185(29.8.2015.), str. 15.

2 IFLA-ine smjernice za narodne knjižnice. Zagreb : Hrvatsko knjižničarsko društvo. 2011. Str. 41. 
naći na pojedinoj od njih te da osnivač mora imati dugoročan koncept gradske knjižnice, a ne pribjegavati ad hoc rješenjima.

Svrha je istraživanja poduprijeti zahtjeve Knjižnice za dugoročnim i na stručnim kriterijima utemeljenim rješenjima.

Ispitivanje zadovoljstva korisnika i mišljenje zaposlenika obavljeno je metodom ankete.

Anketa za korisnike bila je anonimna, u pisanom obliku, dostupna na obje lokacije. Anketa za djelatnike također je bila anonimna, poslana elektroničkom poštom na adrese odjela i ogranaka.

Pitanja su strukturirana na način da predstavljaju kombinaciju pitanja otvorenog i zatvorenog tipa. Sadržajno, pitanja za korisnike obuhvaćaju nekoliko cjelina: opći podaci o ispitaniku, upoznatost s prostornim problemima Gradske knjižnice Rijeka, mišljenje o novoj lokaciji Središnjeg odjela, zadovoljstvo knjižničnim uslugama u novim uvjetima.

Ciljana su skupina korisnici na obje lokacije Središnjeg odjela, ukupno njih 154 , što čini uzorak od $2 \%$ upisanih korisnika Središnjeg odjela te svi zaposlenici na obje lokacije, kao i njihove povremene zamjene, ukupno 23 zaposlenika.

Anketa za zaposlenike sadržajno obuhvaća mišljenje o novoj lokaciji Središnjeg odjela, procjenu zadovoljstva korisnika i uspješnosti vlastitog snalaženja u novim uvjetima.

Korisnici su odabrani na način da uzorak obuhvaća sve dobne skupine, da budu podjednako zastupljene žene i muškarci, stalni i povremeni korisnici, pod uvjetom da žele ispuniti upitnik.

Anketiranje korisnika provodilo se u razdoblju od 22. kolovoza do 2. rujna 2016. godine na obje lokacije Središnjeg odjela, a anketiranje zaposlenika u razdoblju od 19. do 23. rujna 2016.

Anketiranje korisnika i zaposlenika također je i mali doprinos afirmiranju kulture vrednovanja unutar same Knjižnice.

Osim anketiranja korisnika i zaposlenika, u radu su predočeni i usporedni statistički pokazatelji kretanja broja članova Središnjeg odjela Gradske knjižnice Rijeka u razdoblju 2010.-2016. u kojem su prostorni problemi kulminirali i rezultirali raseljavanjem na dvije lokacije. 


\section{Rezultati i analiza ankete}

Slika 1 ilustrira dobnu strukturu korisnika.

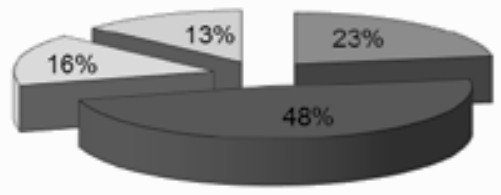

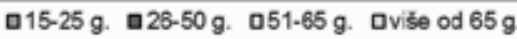

Slika 1. Dob korisnika

Većinu ispitanih činili su korisnici u dobi između 26 i 50 godina (48\%), potom oni između 15 i 25 godina (23\%), a gotovo je podjednako korisnika u dobi 51-65 godina $(16 \%)$ te s više od 65 godina $(13 \%)$.

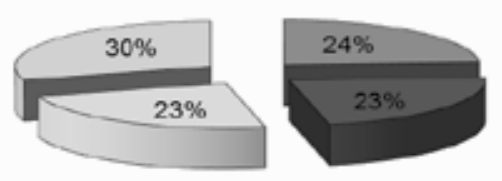

ㅁ0.5 g. ㅁ6-10. g. ㅁ11-20 g. 口ví̈e od $20 \mathrm{~g}$.

Slika 2. Duljina članstva u GKR

Najveći broj ispitanih članovi su Knjižnice više od 20 godina (30\%), dok su ostale kategorije prema duljini članstva podjednako zastupljene među ispitanicima (23-24\%) (slika 2).

Prvo pitanje odnosilo se na upoznatost korisnika s prostornim problemima Knjižnice koji su rezultirali potrebom razdvajanja fonda Središnjeg odjela na dvije lokacije (slika 3). 


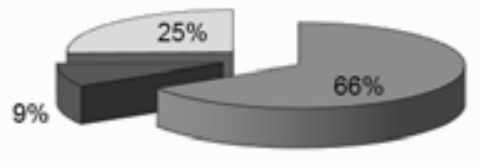

口DA aNE adjelomično

Slika 3. Poznavanje prostornih poteškoća

Većina ispitanih korisnika, čak $92 \%$, izjasnila se da je dobro ili djelomično upoznata s prostornim poteškoćama Knjižnice, a samo $8 \%$ njih nije upoznato $\mathrm{s}$ navedenom problematikom, što upućuje na činjenicu da je dugogodišnje nerješavanje prostornih uvjeta GKR učinilo građane Rijeke svjesnima tog problema.

Korisnici su potom upitani smatraju li da je razdvajanje fonda Središnjeg odjela zadovoljavajuće rješenje prostornih problema Knjižnice. Slika 4. ilustrira njihove odgovore.

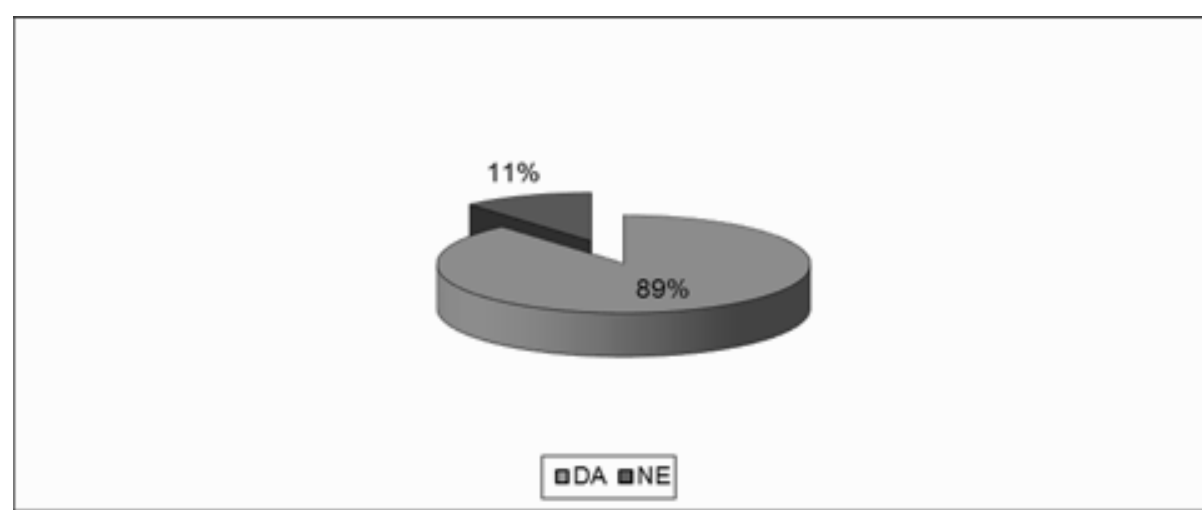

Slika 4. Prihvatljivost razdvajanja fonda Središnjeg odjela na dvije lokacije

Čak $89 \%$ ispitanih korisnika afirmativno je ocijenilo razdvajanje Odjela na dvije lokacije. Uz to ističu da su svjesni da je rješenje "vatrogasno" i trenutačno, odnosno da ne očekuju da bude trajno. Moguće je da je takav odgovor rezultat krajnje loših prostornih uvjeta u kojima je godinama djelovao Središnji odjel Knjižnice, što su korisnici dodatno pojasnili u pisanim komentarima istaknuv- 
ši razloge koji se tiču dostupnosti, pristupačnosti i preglednosti građe te većeg i ugodnijeg prostora.

$\mathrm{Na}$ identično pitanje većina djelatnika, točnije 15 od njih 23, odgovara kako smatra rješenje dobrim kao trenutačno. Značajnih 8 od 23 ispitana djelatnika smatra da rješenje nije primjereno ni kao trenutačno.

Sljedeće pitanje odnosilo se na to jesu li korisnici u potpunosti upoznati s time koje skupine knjiga (stručna literatura, beletristika i sl.) mogu pronaći u Palači Modello, a koje u Filodrammatici (slika 5).

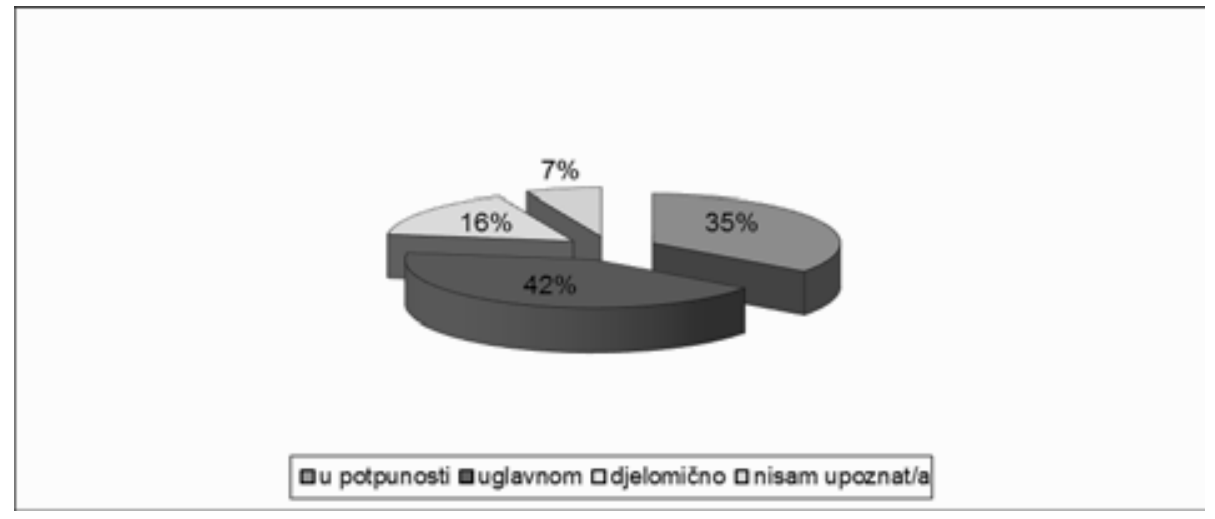

Slika 5. Upoznatost s načinom razmještaja fonda na dvije lokacije

Bez obzira na to što se fond razdvojio prema velikim signaturnim skupinama i što se uložio napor u informiranje korisnika o grupiranju fonda po lokacijama, samo $35 \%$ ispitanih smatra da je dobro upoznato s razmještajem. Udio od $22 \%$ ispitanih, što nije zanemariv broj, je djelomično upoznat ili nije upoznat s razmještajem fonda.

Ostatak od $43 \%$ ispitanih, koji smatraju da su uglavnom upoznati s navedenim, u svojim je pisanim komentarima istaknuo da pri svakom posjetu Knjižnici moraju razmišljati kojoj lokaciji pripada pojedina knjiga te da vrlo često pogriješe.

Zadatak da ocijene svoje snalaženje u novom razmještaju fonda Središnjeg odjela na dvije lokacije s obzirom na signaturne skupine postavili smo i djelatnicima.

Odgovori djelatnika da je njih 9 od 23 u potpunosti sigurno što je smješteno na kojoj od lokacija, 12 uglavnom sigurno, a 2 povremeno nesigurno pokazuju da uz sve dogovore i više od godinu dana rada na dvije lokacije koncept još nije zaživio, jer bi se u suprotnome moglo očekivati da će u većem postotku biti zastupljen odgovor u potpunosti sigurno.

Lokacija Knjižnice u zgradi Filodrammatica nalazi se neposredno uz ugostiteljski objekt te su korisnici zamoljeni da iskažu svoje mišljenje o tome (slika 6). 


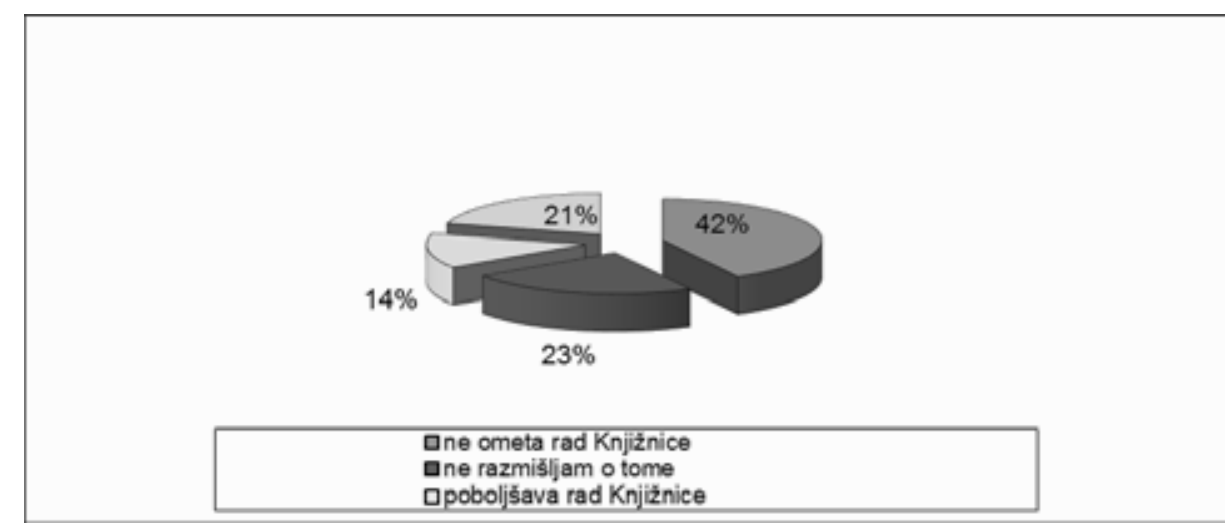

Slika 6. Ocjena smještaja Knjižnice uz ugostiteljski objekt

Nova lokacija Središnjeg odjela smještena je uz ugostiteljski objekt na način da se u Knjižnicu ulazi kroz terasu i unutrašnjost kafića te na drugi, bočni ulaz koji je još slabije vidljiv i loše označen.

Da je smještaj Knjižnice uz ugostiteljski objekt neprimjeren i otežava rad smatra $21 \%$ korisnika, $23 \%$ korisnika o tome ne razmišlja, $14 \%$ njih smatra da ta činjenica čak poboljšava rad Knjižnice, dok većina od $42 \%$ smatra da blizina kafića ne ometa rad Knjižnice.

Kad je riječ o djelatnicima koji na navedenoj lokaciji provode cijelo radno vrijeme, 15 od 23 ispitanih djelatnika smatra da blizina ugostiteljskog objekta ometa rad Knjižnice.

Djelatnici su naveli otežavajuće aspekte sljedećim redoslijedom: neprekidan žamor i glazba iz kafića, nedovoljna i neprimjerena označenost lokacije i sadržaja Knjižnice, zajednički ulaz s kafićem, mirisi iz ugostiteljskog objekta.

Iz svega navedenog proizlazi da blizina ugostiteljskog objekta sama po sebi ne bi bila problem pod pretpostavkom partnerskog odnosa dvaju subjekata u kojem bi se poništili negativni učinci te optimalno i obostrano iskoristile prednosti.

Nakon razdvajanja fonda Središnjeg odjela korisnici ponekad moraju otići na obje lokacije da bi odabrali željene knjige te je jedno od pitanja bilo i u kojoj im to mjeri predstavlja problem (slika 7). 


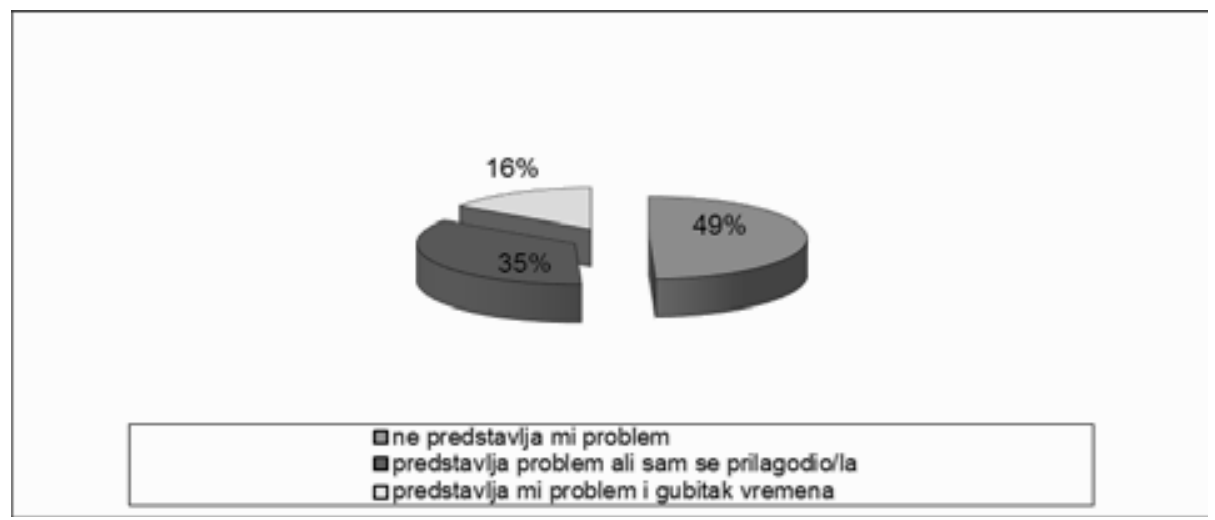

Slika 7. Jednostavnost korištenja Knjižnice na dvije lokacije

O teškoći odlaska na dvije lokacije korisnici su se izjasnili različito.

Nešto više od polovice izjasnilo se da im to predstavlja problem ili im predstavlja problem, ali su se prilagodili. Nešto manje od polovice izjasnilo se da im to ne predstavlja problem. Oni kojima to ne predstavlja problem u svojim pisanim komentarima istaknuli su da su pretežno čitatelji beletristike ili pretežno čitatelji stručne literature i da novu lokaciju doživljavaju kao promjenu i osvježenje.

Na zamolbu da ocijene nove prostorne uvjete ispitani korisnici uglavnom su se izjasnili pozitivno (slika 8).

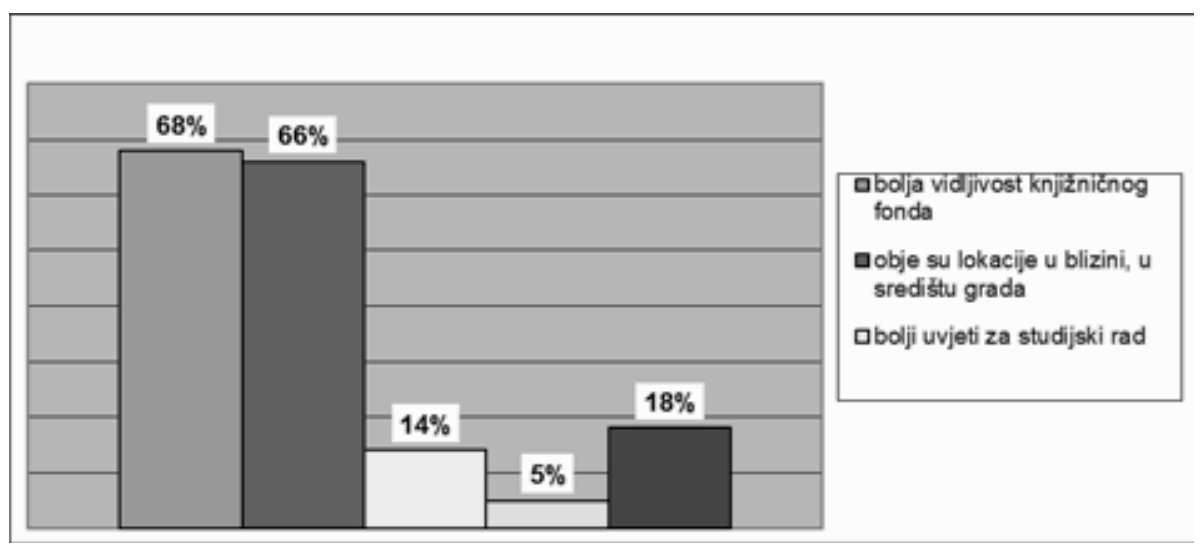

Slika 8. Ocjena novih prostornih uvjeta Središnjeg odjela na dvije lokacije

Pozitivna ocjena odnosi se većinom na bolju vidljivost knjižničnog fonda i smještaj obiju lokacija $u$ blizini, u središtu grada. Daljnji pozitivan aspekt, ali u znatno manjem postotku, odnosi se na poboljšanje uvjeta za studijski rad. 
Ipak, gotovo četvrtina korisnika ne smatra da su se prostorni uvjeti poboljšali, a većina njih misli da rad na dvije lokacije poništava učinak ukupno većeg prostora.

Kad je riječ o djelatnicima, također je na prvom mjestu bolja vidljivost knjižničnog fonda. Nadalje, djelatnici podjednako vrednuju bolje uvjete za studijski rad i blizinu lokacija, dok korisnici prednost daju međusobnoj blizini lokacija.

Ukupno 8 od 23 djelatnika smatra da smještaj na dvije lokacije umanjuje učinak ukupno većeg prostora.

Korisnici su također upitani je li po njihovu mišljenju ukupno povećanje prostora Središnjeg odjela radom na dvije lokacije pozitivno ili negativno utjecalo na kvalitetu knjižničnih usluga (slika 9).

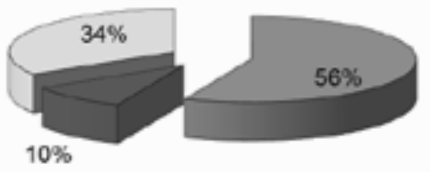

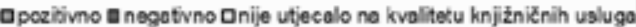

Slika 9. Utjecaj ukupnog povećanja prostora na kvalitetu knjižničnih usluga

Više od polovice ispitanih korisnika smatra da je povećanje ukupnog prostora Središnjeg odjela pozitivno utjecalo na kvalitetu knjižničnih usluga. Međutim nije zanemariv udio od $34 \%$ onih koji smatraju da to nije utjecalo na kvalitetu knjižničnih usluga, a 10\% smatra da je utjecaj bio negativan.

Ti su rezultati u neposrednoj vezi sa specifičnim korisničkim potrebama koje su artikulirane u pisanim odgovorima (slika 10).

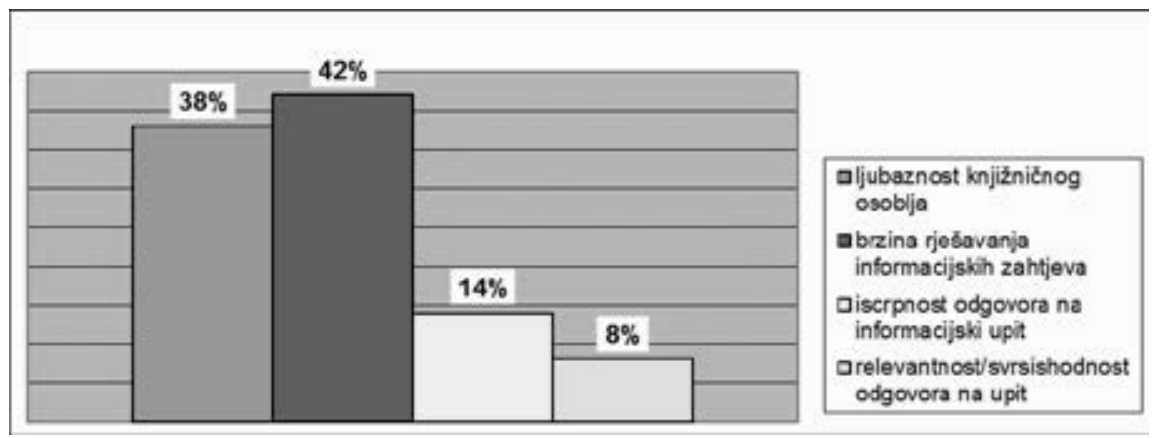

Slika 10. Aspekti usluga na koje je preseljenje utjecalo pozitivno 
Procjena pozitivnih aspekata od strane korisnika odnosi se prvenstveno na brzinu rješavanja korisničkih zahtjeva, veću ljubaznost i posvećenost korisnicima u novim prostornim uvjetima. Slijedi iscrpnost i relevantnost odgovora na korisničke upite.

Percepcija djelatnika o zadovoljstvu korisnika pokazuje da više od polovice ispitanih djelatnika procjenjuje da korisnici nisu zadovoljni razdvojenim lokacijama, ali da je većina to prihvatila kao nužnost.

\section{4. Analiza pisanih komentara korisnika}

Pisane komentare korisnika možemo okvirno grupirati u tri skupine: komentari koji se odnose na prostorne probleme Knjižnice, komentari o osoblju Knjižnice i komentari koji daju prijedloge za uklanjanje problema. U nastavku ćemo detaljnije pojasniti svaku skupinu komentara.

- Komentari koji se odnose na prostorne probleme Knjižnice

Korisnici su u velikom broju konstatirali da Grad Rijeka, građani i knjižnični djelatnici zaslužuju primjerenu knjižnicu u kojoj će biti dovoljno prostora za sve knjižnične servise i usluge.

Smatraju da je Knjižnica u ovim uvjetima ograničena u naporima za unapređenje čitateljskih interesa te iskazuju suosjećanje s osobljem Knjižnice koje po njihovu mišljenju zaslužuje raditi u primjerenim uvjetima.

Ispitanici u većem broju ističu da im je velik problem razmišljati o tome gdje moraju posuditi određenu knjigu, ali isto tako i gdje ju trebaju vratiti. Smatraju da im je to napor i gubitak vremena. Navode da je sve to za njih zbunjujuće.

U takvoj situaciji zadovoljstvo iskazuju oni koji koriste isključivo jednu lokaciju, odnosno posuđuju samo beletristiku ili samo stručne knjige.

Ispitanici ističu da su svjesni nužnosti takva stanja, smatraju ga privremenim i očekuju od osnivača - Grada Rijeke - da pristupi konačnom rješavanju problema.

Pozdravljaju otvaranje nove lokacije kao privremenog rješenja smatrajući da je svaki novi knjižnični odjel bogatstvo za građane.

- Komentari koji se odnose na osoblje Knjižnice

U većem broju korisnici su se osvrnuli na knjižnično osoblje, i to uglavnom pozitivnim i afirmativnim opaskama.

Smatraju da je osoblje ljubazno i sada i ranije, da je stručno i profesionalno, da se dovoljno trudi i zaslužuje bolje uvjete rada.

- Komentari koji ukazuju na ključ rješenja

Ispitanici su pokazali da razumiju da je ključ rješenja prostornih problema u rukama osnivača, tj. Grada Rijeke. 
Pozivaju Grad da dugoročno riješi pitanje prostora Knjižnice iznalaženjem adekvatnog prostora kakav građani zaslužuju:

Dok se ne izgradi nova gradska knjižnica, Rijeka ne može biti europska prijestolnica kulture!!

Obi (gradonačelnik Obersnel, op.a.) što se čeka!

\section{Analiza statističkih pokazatelja}

U ovom dijelu rada donosimo statističke pokazatelje preuzete iz godišnjih izvješća o radu Knjižnice, a generiranih iz knjižničnog programa ZaKi.

Tablica 1. Usporedni pokazatelji kretanja broja članova i posudbe tijekom prvih šest mjeseci 2010.-2016.

\begin{tabular}{|c|c|c|}
\hline Godina (1.-6. mj.) & Članovi & Posudba \\
\hline 2010. & 4.756 & 137.473 \\
\hline 2011. & 4.413 & 131.346 \\
\hline 2012. & 4.617. & 118.290 \\
\hline 2013. & 4.301 & 122.238 \\
\hline 2014. & 4.123 & 126.365 \\
\hline 2015. & 4.225 & 102.978 \\
\hline 2016. & 4.139 & 116.742 \\
\hline
\end{tabular}

Analiza statističkih pokazatelja o broju članova i kretanju posudbe u razdoblju od 2010. do 2016. g. pokazuje da i članstvo i posudba uglavnom stagniraju te da se razdvajanjem fonda na dvije lokacije nije dogodio iskorak koji bi taj trend stagnacije okrenuo u pozitivnom smjeru.

Broj posuđenih knjiga 2016. veći je nego 2015., no pretpostavljamo da je razlog tomu višemjesečna nedostupnost značajnog dijela fonda zbog urušavanja spremišta.

U odnosu na 2014. radi se pak o smanjenju posudbe za 7,6\% iako bi se moglo očekivati da će zbog bolje dostupnosti fonda ona biti barem na istoj razini, ako ne i veća.

\section{Zaključak}

U ovom trenutku ne znamo kada će nova zgrada središnje knjižnice biti realizirana te se ulažu dodatni napori u osmišljavanju koncepata tih dviju lokacija istog 
knjižničnog odjela, prve koja nudi pretežno beletristiku i druge koja nudi stručne knjige.

Rezultati ankete potvrdili su većinu naših polaznih pretpostavki:

- da korisnici znaju vrednovati dodatno dodijeljeni prostor Središnjem odjelu Gradske knjižnice Rijeka jer se u njemu dijelovi fonda mogu bolje prezentirati

- da korisnici znaju procijeniti je li dodijeljeni prostor primjeren ili ne te može li on biti dugoročno rješenje ili ne

- da korisnici u bliskoj budućnosti očekuju na istoj lokaciji sve sastavnice općeg fonda Knjižnice

- da korisnici razumiju prirodu javnog servisa za građane te da mogu procijeniti obvezu osnivača prema istome

- da je ključ rješenja u rukama osnivača.

Rezultati ankete iznenadili su nas u nekim polaznim pretpostavkama:

- korisnicima ne smeta susjedstvo kafića i Knjižnice, štoviše, to smatraju pozitivnim dinamiziranjem urbanog života.

$\mathrm{Na}$ temelju rezultata ankete i statističkih pokazatelja razvidno je da ponuđeni i realizirani izlaz iz situacije koja je zahtijevala hitno rješavanje nije dugoročno rješenje problema fizičkog prostora Središnjeg odjela Gradske knjižnice Rijeka.

Usprkos negativnim predviđanjima, u svijetu se grade zgrade za narodne knjižnice. Od posljednjeg desetljeća 20. st. do danas u Hrvatskoj su riješeni prostorni problemi mnogih narodnih knjižnica u većim i manjim gradovima (Split, Zadar, Šibenik, Pula, Bjelovar, Karlovac, Ilok, Benkovac, Labin...), i to adaptacijom i dogradnjom postojećih prostora. Rijeka je tako ostala među malobrojnim primjerima u kojima izgradnja ili adaptacija prostora za narodnu knjižnicu nije bila jedan od prioriteta za osnivača. Time Gradska knjižnica Rijeka nije u mogućnosti u potpunosti ispunjavati svoju misiju prema proklamiranim međunarodnim i domaćim dokumentima.

Naime u vremenu tranzicije narodnih knjižnica iz baštinskih ustanova u mjesto "trećeg prostora"’ za građane, pojam knjižnice kao fizičkog mjesta ne gubi, već, upravo suprotno, dobiva na važnosti. „Kako bi knjižnice mogle djelovati i kao „treći“ prostor, fizička površina kojom knjižnice raspolažu te prostor za korisnike i oprema bitan su čimbenik ispunjavanja te zadaće knjižnice.“4

3 „Riječju, korištenje knjižnice kao trećeg prostora u cijelosti je određeno svrhom knjižnice“. Vidi: Velagić Zoran. Povijesnost koncepcije trećeg prostora. // Narodne knjižnice kao treći prostor : zbornik radova / 9. savjetovanja za narodne knjižnice u Republici Hrvatskoj ; [urednice: Dunja Marija Gabriel, Jelica Leščić]. Zagreb : NSK, 2015. Str. 40.

4 Gabriel, Dunja Marija; Jelica Lešćić. Prostori narodnih knjižnica u Hrvatskoj. // Narodne knjižnice kao treći prostor : zbornik radova / 9. savjetovanje za narodne knjižnice u Republici Hrvatskoj ; [urednice: Dunja Marija Gabriel, Jelica Leščić]. Zagreb : NSK, 2015. Str. 93. 
Sličnog su mišljenja bili i naši ispitanici. U nastavku donosimo komentar iz upitnika za zaposlenike:

“....uistinu smatram kako ovaj grad, građani i djelatnici knjižnice zaslužuju vrhunsku novu i posebnu zgradu knjižnice i da je ovo rješenje samo nešto što je zaustavilo i požar i poplavu, ali istovremeno odvajam prostor od ljudi, loše od dobroga $i$ veseli me svaka promjena iz koje mogu izvući barem nešto dobro - radeći programske sadržaje iz ove priče izvukla sam mnoge dobre momente kakvi su bili nemogući u prethodnoj. Isto tako znam da bi u onoj pravoj priči u kojoj zaista imamo knjižnicu dostojnu građana naš posao mogao biti prava raskoš i pjesma koju znamo izvrsno pjevati, ali neki koji odlučuju očito nemaju sluha pa mi i dalje sviramo u garaži. A znamo, riječka priča... najbolji bendovi nikad nisu snimili ploču, ali se i danas priča o njima... " (citirano uz odobrenje)

\section{LITERATURA:}

Gabrijel, Dunja Marija; Jelica Leščić. Prostori narodnih knjižnica u Hrvatskoj. // Narodne knjižnice kao treći prostor : zbornik radova / 9. savjetovanje za narodne knjižnice u Republici Hrvatskoj ; [urednice Dunja Marija Gabriel, Jelica Leščićc. Zagreb : NSK, 2015. Str. 85-98.

IFLA-ine smjernice za narodne knjižnice. Zagreb : Hrvatsko knjižničarsko društvo. 2011.

Standardi za narodne knjižnice u Republici Hrvatskoj [citirano: 2017-03-20]. Dostupno na http://narodne-novine.nn.hr/clanci/sluzbeni/1999_06_58_1071.html.

Šestan Kučić, Ingrid. Tijekom 20 dana posuđeno osam tisuća naslova. // Novi list 69, 22185(29.08.2015.), str. 15.

Velagić, Zoran. Povijesnost koncepcije knjižničnoga trećeg prostora. // Narodne knjižnice kao treći prostor : zbornik radova / 9. savjetovanje za narodne knjižnice u Republici Hrvatskoj ; [urednice Dunja Marija Gabriel, Jelica Leščićc. Zagreb : NSK, 2015. Str. 29-42. 